\title{
Tales of the global city: German expatriate employees, globalisation and social mapping.
}

\author{
By Fiona Moore (Kingston University School of Business).
}

Transnational business people are seldom studied by anthropologists. They are inexorably linked to cities through the nature of their work and yet detached from them by virtue of their globe-trotting lifestyles. Here, I examine the role that two 'global cities' - London and Frankfurt - play in the lives of a group of employees from a German transnational financial corporation. I consider how these employees construct, and are constructed by, the cities in which they work and suggest that anthropologists may have to rethink our present conception of 'the global' versus 'the local', in favour of more abstract models.

Transnational business people have a distinctive relationship with the urban: such individuals are at once strongly associated with cities through the nature of their work, and detached from them by virtue of their globe-trotting lifestyles. As a consequence, they are inexorably linked to the development of a particular recent urban form: the so-called 'global cities'. An examination of how a particular group of employees of a German transnational financial corporation construct social maps within the cities of London and Frankfurt should, therefore, have significant implications for the ways in which anthropologists conceive of the relationship between 'global' and 'local' spaces.

\section{Theoretical overview: global cities and social maps}

As transnational groups become more dissociated from particular nations they become concentrated in those cities that form the hubs of transnational social networks. In this section, I will discuss the concept of 'global cities', and suggest ways in which anthropological theories of 'social maps' might be useful in understanding the nature of the construction of space among transnational business people.

'Global cities', a term coined by Saskia Sassen (1991), are cities which 'are key command and control points in the global economy' (Jones 2002: 336); more specifically, they are cities which have as many social and communicative ties to other cities around the world as to locations in their own countries, if not more. Manuel Castells and others argue that the dominant social form under globalising conditions is the cross-border network, and that global cities come to form the nodal points of these networks (Taylor et al. 2002: 95). (Although some researchers, for instance Jones 2002, argue that the networks are more diffuse and individual-focused than Sassen and Castells' formulations suggest, global cities are generally believed to form the social focus points for transnational activities.) 
Transnational elite business people are particularly strongly associated with the development of global cities (Beaverstock 2002; see also Hannerz 1996). These are business people who move, over the course of their career, between different international locations with a view to facilitating the global integration of corporations, or whose work involves coordinating the flows of information and capital between such locations (Sklair 2001). Beaverstock notes how transnational business people concentrate themselves within global cities in order to maintain the face-to-face contact that is necessary for accumulating knowledge (2002). Knowledge is accumulated not only in offices, but in bars, restaurants and other leisure areas where expatriates and globally-engaged locals form networks and exchange information (Beaverstock 2002: 533-4). Transnational elite business people thus congregate in global cities in order to acquire the contacts and information necessary for them to prosper in the global business environment, and, in doing so, further the city's orientation towards the global (535). Consequently, it seems likely that the 'global' status, of such cities is associated to some degree with transnational business people's 'social maps'; that is to say how they 'perceive and pattern' their world in spatial terms, and in turn have their social arrangements shaped by physical geography (Ardener 1993: 1, 3). Jones argues that, 'the physical location is to all intents and purposes an arbitrary physical context... the place or location of command and control functions is not a good epistemological focus for theories of the global economy' (Jones 2002: 337). Moreover, because the global city concept bears such strong links to the ways in which people order their social world in terms of increasing or decreasing relations to physical spaces, then it seems that in order to understand the nature of global cities we must consider how persons construct their surroundings through individual social maps.

'Global cites' are thus cities which, in social terms at least, appear more detached from local concerns and are becoming increasingly engaged with transnational networks. As such their 'global' status is furthered by the presence of transnational elite business people and influence the ways in which these individuals regard their world. We shall now consider how a group of business people employed by a German bank construct, and are constructed by, their association with the global cities of London and Frankfurt.

\section{Methodology}

This project is based on an ethnographic study, which was carried out at a German multinational bank between January 2000 and January 2001. The material consists of, firstly, observation of and participation in the office environment, which involved coming in to the bank every working day and having access to a desk in a shared office, the canteen and other basic staff resources, and meeting rooms in which to conduct formal interviews, and secondly, of formal and informal interviews with a number of people within the bank and outside of it.

Perhaps unsurprisingly, given the association of transnational businesspeople with social networking, access to the field site was gained through social connections; I was introduced to the General Manager of the bank by a colleague who was the chairman of a German business networking organisation, and came to an agreement with him whereby, in exchange for research access to the corporation, I would submit a report to the bank's management on the cultural issues which I had encountered. The main research problems in this area were, firstly, the fact that my 'official' 
position as a 'consultant on cultural issues', while allowing me to gather extensive ethnographic data, also coloured the way in which people related to me; I was keenly aware that my interviewees all knew that I would later be preparing a report which would be read by, among others, the personnel manager. I also found that the sort of extensive, ongoing access which many anthropologists studying traditional groups or even manufacturing organisations - was impossible in this case, as banks tend to restructure themselves, changing in form and composition, every couple of years. I compensated for these issues by, in the first instance, being aware of where each of my interviewees stood within the politics of the organisation, and secondly, by approaching my project less as a long-term study than as an intensive portrait of a particular organisation at a particular moment in time.

Formal interviews were conducted on a periodic basis with 16 individuals at the London branch and seven at the Frankfurt head office of the bank. Of these, 18 were German (11 at the UK branch, seven at the German head office) and five were of UK origin (all at the UK branch). The people interviewed were mainly junior and middle managers, with five members of top management and two non-managerial staff members also participating. Each participant was interviewed between one and four times, with interviews lasting approximately an hour apiece. Bilingual interviewees were given the option of being interviewed in English or German. These interviews were also complemented by informal interviews and conversations with these and about twenty other staff members: these followed no set pattern, although I made certain to ask whether or not I could use the relevant part of the conversation in my study, and were usually conducted over lunch or after work.

In addition, I conducted formal interviews with a total of 34 key figures in London's German and financial communities, including representatives of the Bank of England, the Corporation of London, and the Deutsche Bank, as well as of five German business and five German cultural support organisations, three educational organisations and relocation agencies, and a total of seven business think-tanks and consultancies. Access to these individuals was largely gained through the social networking connections of my interviewees from the bank under study. Also, while in pubs or cafes in London or Frankfurt, I made a point of observing and noting down the activities and behaviour of the people around me.

By not only interviewing transnational business people with connections to both Germany and the UK, but also sharing their lifestyle, travel patterns and places of residence, I aim to understand the role which the global city plays in their social interaction. I shall now consider the global cities in question, London and Frankfurt, and how they figured in my interviewees' social maps.

\section{The cities}




\section{a) London}

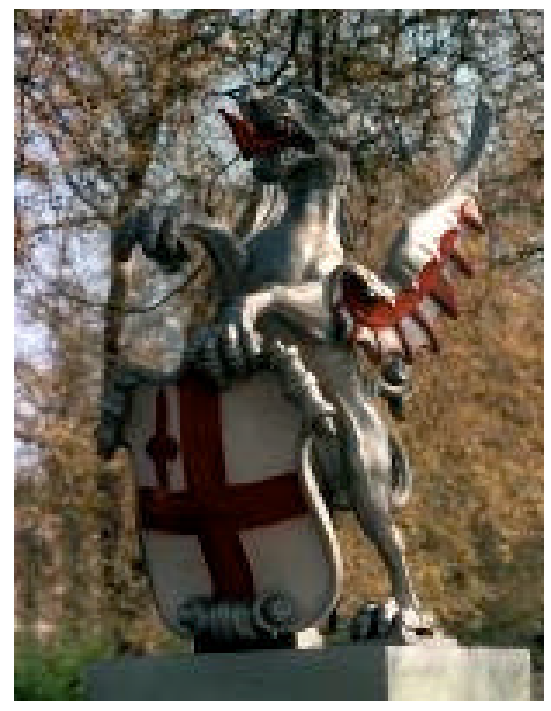

Fig 1. The silver dragons marking the boundaries of The City.

(C) Daily Mirror Picture Library.

The City of London (also known as 'The City' or 'The Square Mile') is an area of approximately one square mile near the centre of London, the political and economic capital of the United Kingdom. Whilst The City's physical boundaries are marked by statues of silver dragons, its symbolic boundaries are somewhat vaguer as an increasing number of companies are establishing positions some miles further east in Canary Wharf, which as late as 1996 was still seen as a sort of exile or hinterland (Augar 2000: 18). The City has been occupied since Roman times, whilst its present government, the Corporation of the City of London, dates from the ninth century (Jenkins 1988: 6). The City was largely locally-focused up until the founding of the Bank of England in the $17^{\text {th }}$ century, at which point it began to expand its global interests (Jenkins 1988). Its glory period was between 1810-1914, when it covered both global financial and mercantile functions and was supported by Britain's position as the era's dominant economic and military power. After World Wars I and II, and the consequent fall of the British Empire, The City became more financially specialised, but continued to retain international connections (Courtney and Thompson 1996; Rose 1994). The City of London thus has an extensive history of participation in global trade and financial activity, and remains both legally and socially distinct from the rest of London, to say nothing of the United Kingdom.

My interviewees cited three main factors as drawing companies to the area, all of which are consistent with Beaverstock's descriptions of the attractions of global cities for transnational business people (2002). The first is the networking potential of having an office in the same area as other corporations in the same field (Beaverstock and Smith 1996: 1379): one interviewee and think-tank member remarked that even in these days of instantaneous global communication, "buzz" counts for a lot'. The second, as another interviewee noted, is credibility: for all financial corporations, having a London office offers symbolic status, indicating that the corporation has a global presence. The third factor is the large and mobile pool of skilled labour which The City boasts. This creates a snowball effect, for, as companies come to London for the labour pool, skilled professionals are attracted to London for employment. Moreover some interviewees, who were more financially knowledgeable, pointed out 
a fourth reason: namely that, since the 'deregulation' of the mid-1980s, The City has had more lenient tax laws and a much less strict regulatory system than the rest of the UK, and indeed than many countries, including the USA (Augar 2000: 49). All of these factors cause The City to be dominated by foreign financial corporations, and to have, if anything, more contact with other global cities than with the other large cities of the UK.

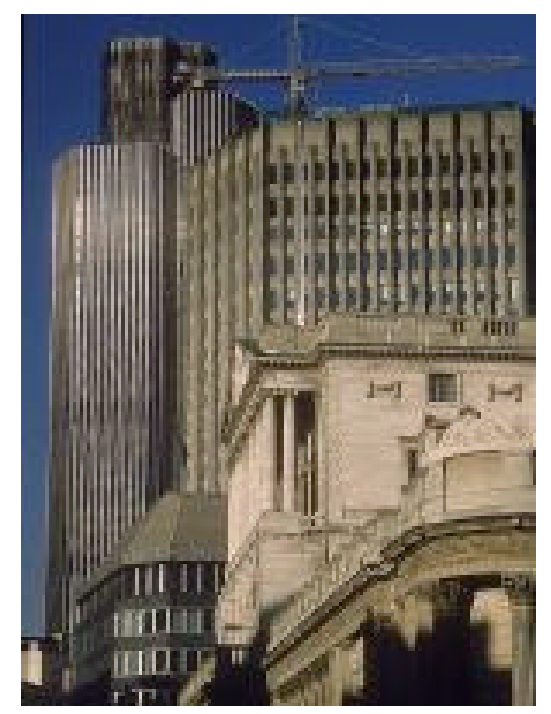

Fig. 2. The mixture of architectural styles in The City.

(c) Daily Mirror Picture Library.

The City's distinctive 'global' status is highly visible to anyone walking through the area. The architecture is a cosmopolitan mix, with streets of elegant Georgian houses (now mostly housing think-tanks and small consultancies) standing alongside glossy glass-and-concrete towers. The streets are narrow and winding, but are cleaner and better lit than those in most other parts of London, in line with the expectations of people from outside the UK. The City boasts several Georgian and Victorian churches, which attempt to draw in the business crowds with signs advertising lunchtime concert recitals and 'lectures on modern issues' rather than sermons, indicating a willingness to embrace visitors of different faiths and origins. Workers walking around the streets dress in near-identical suits, and accents from the Southeast of England dominate; however, a visible - and audible - number are from other countries. A Canadian friend who visited me remarked that he had identified five separate languages on the short journey between London Bridge and St Paul's. The City's financial focus is seen everywhere: for, whilst there are few of the LED stockmarket quote displays which characterise the financial districts of New York and Frankfurt, nearly every building bears the name of a financial firm and boasts at least one security guard on reception. Even The City's architecture and population indicate its distinct status, and link it more to other cities around the world than to the UK and, one might argue, to the rest of London itself. 


\section{b) Frankfurt-am-Main}

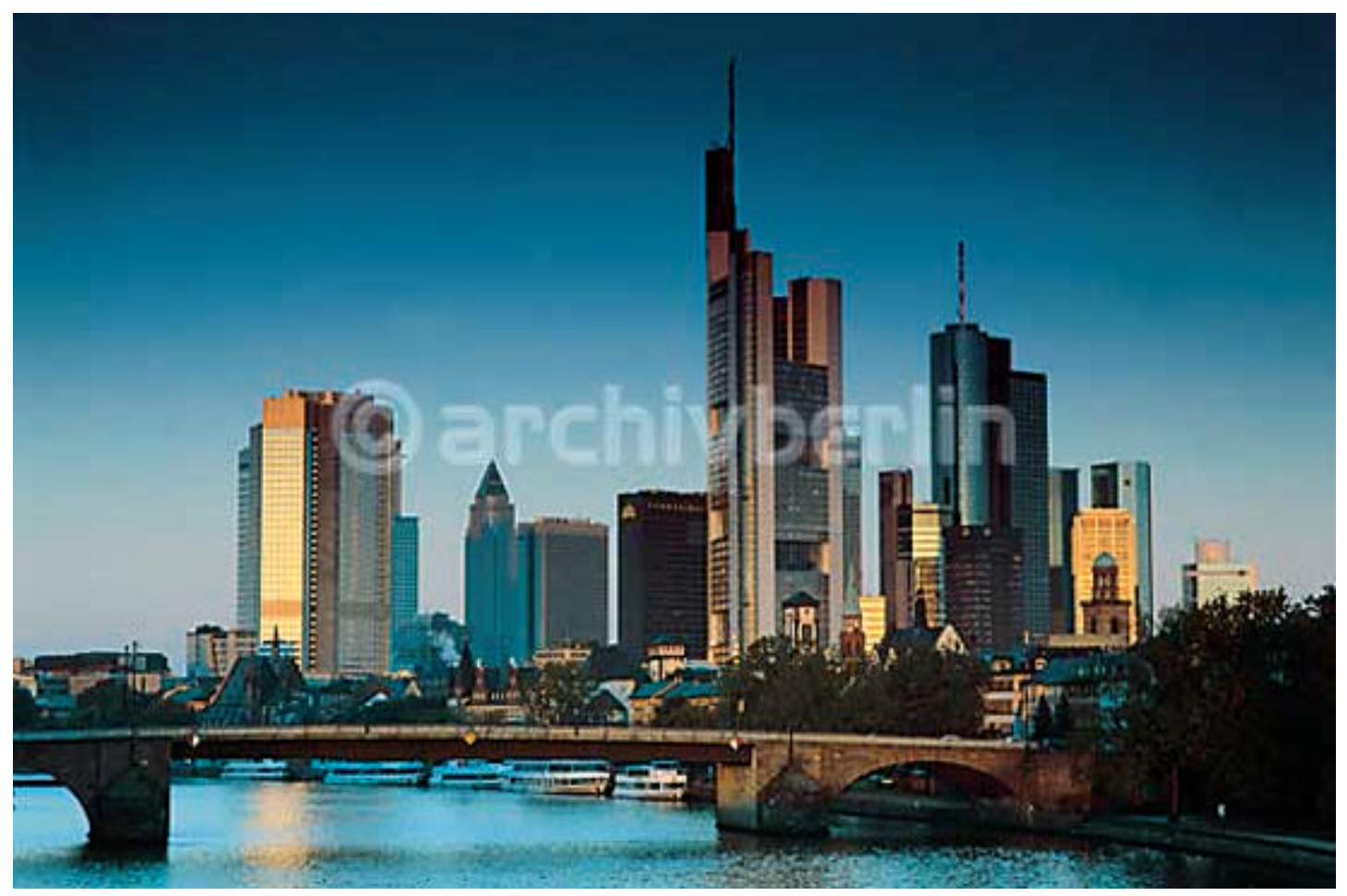

Fig 3. View of the skyline of Frankfurt from the river Main. (C) Archivberlin Picture Library.

By contrast, Frankfurt-am-Main's global credentials are less visible and do not possess the same historical depth. Situated on the Main river in the German state of Hesse, its mercantile activities were mostly locally focused until the end of WWII, with Berlin being the primary centre of international financial activity (Gall et al. 1995). After WWII, the victorious Allies decided to establish Frankfurt as the economic capital of West Germany, partly because of the inherent risk of having the major international banks situated in Berlin (which was perceived as being at risk of Communist takeovers), and partly due to a conscious decision to decentralise the major political and economic functions of the new state (402-486). Unlike London, the geographical boundaries of the financial district are fuzzy, extending randomly over much of the area near the river and being characterised by massive office blocks of recent origin rather than by adapted older buildings. Although Frankfurt has remained the economic capital of reunited Germany, the legacy of decentralisation is visible in the fact that Beaverstock et al.'s survey of global cities demonstrates that there are seven cities with a fair degree of globalisation in Germany, whereas in the UK there is only London (2001: 13). Although Frankfurt's tourist and PR information tends to play up its mercantile past, it is not a global city of long historical, cultural and political depth in the same way that London is, and its global connections are less obvious and more subject to internal competition.

The main asset which Frankfurt has as a global city is its predominance within the European market. The establishment of the European Central Bank in Frankfurt (rather than in London) has caused many to speculate that, as Beaverstock et al. note (2001: 9), "it might be "catching up" with London or even poised to take over its leadership position' (Sassen 2002: 18). Frankfurt is generally perceived to be the upand-coming financial centre in Europe, and there has recently been a small industry of 
writing (in both cities) on the possibility that Frankfurt might surpass London as Europe's premier global city in business terms (e.g. Lascelles 1999). Although this has not yet come to pass, one cannot help but notice that Frankfurt is a global city in a quite different way to London: that, in Beaverstock et al.'s words, 'London [is] a supreme "all-rounder" world city with a global presence, and Frankfurt [is] an international financial service centre with a largely European remit.'(2001: 13). Therefore, although Frankfurt may also be a nodal point in global financial networks, it is one that displays quite different connections to those found in London.

Frankfurt's global orientation is less obvious than London's; most of the business people one encounters on the street are European, if not German and, although a wrong turn can easily lead one into one of the Turkish districts, non-Europeans are not strongly represented in the financial districts. It does, however, strongly advertise its European connections: European Monetary Union was as significant an event for Frankfurt as deregulation was for London (if not more so), with Euro-themed toys, Tshirts and sweets being available in most Frankfurt tourist shops, and in September 2000 the city held a competition in which schoolchildren and artists decorated fourfoot-high Euros, which were then auctioned off for charity. American-style LED displays are common throughout the financial district, and English is frequently overheard. Thus, whilst London and Frankfurt are undeniably 'global cities' according to the reckoning of Sassen and her colleagues; they are both 'global' in quite different ways and with quite different orientations towards the world. We shall now consider how the two cities are constructed by the transnational business people who form the subject of my study, and how they relate to the cities.

\section{Constructing the city: transnational business people and their social maps}

My interviewees, not surprisingly, appear to construct London as a 'global' and Frankfurt as a 'European' city. However, in doing so, they draw upon their definitions of both cities, and of issues of what it is to be 'global' and 'local'. In fact, their constructions of the cities incorporate both global and local influences, and include the connections between the two.

Most of my interviewees described the City of London as culturally 'closer' to New York and Tokyo than to the rest of England; when asked the question 'Is The City English?', all of my interviewees responded in the negative, some adding that while it was in England, it was not English. Germans looking for 'real Englishness' went to Oxford, Stratford-upon-Avon, or tourist sites elsewhere in London such as Buckingham Palace. Local features, such as the class tension within The City, were largely unmentioned; moreover, whilst the Germans were not unaware of the class tensions (several trainees expressing puzzlement at the lack of emphasis on university qualifications in The City), for the most part this was not discussed. On the other hand, they also tended to define The City in terms of its English or 'Anglo-Saxon' business culture, as opposed principally to the German one (Binney 1993; Millar 1979). Interestingly, this Englishness can paradoxically be seen as a form of cosmopolitanism, given that English is seen as the 'global language' and American business culture remains the hegemonic form. Although The City is constructed as 'global', my interviewees nevertheless refer to various sorts of local connections as well. 
Interviewees also focused on the simultaneous global and local connections of The City's financial activities. Its distinctive tax and regulation systems figured heavily in interviewees' descriptions. Symbols of consumption also featured prominently; Lewis, an American trader who worked for a while in the City, attributes the popularity of London as a location site for American banks to 'its time zone, its history, its language, its relative political stability, its large pool of dollar-hungry capital and Harrods' (1989:184). Most of the German interviewees similarly focused on the consumption possibilities afforded by The City's location; virtually all visitors to the bank went out to a West End musical and/or shopping on Oxford Street as part of their visit. Again, for Germans, partaking in these activities was seen as defining oneself as a cosmopolitan world traveller. In doing so, transnational business people thus refer to The City's global nature through symbols which not only define local English culture, but also local German images of cosmopolitanism.

Furthermore, the historical depth and global business activities of The City were also described in ways that reflect the interviewees' priorities. My English interviewees spoke in general terms about how The City had 'always been global', pointing out $18^{\text {th }}$ century markets and Roman archaeological sites, whereas the Germans' descriptions of historical symbols figured primarily from a practical or aesthetic standpoint, and historical buildings and churches were talked about as objects of beauty or places to go to for a bit of peace and quiet at lunchtime. (On more than one occasion, I discovered a businessman in the rear pew of one or the other of The City churches, busily doing office work.) Deregulation, more curiously, did not seem to be of much concern to the Germans, whereas English people at the same banks referred to it continually; in fact, only one German interviewee even mentioned it, and he had been in London for over thirty years and had worked for English and American banks prior to working for a German one. The lack of emphasis on deregulation may quite likely be because it is eclipsed, in most Germans' minds, by the events of the German reunification and the development of a common European currency (see Watson 1995; Gullick 1993: 207-209). Other Germans were not unaffected by the change, as the English employees who mentioned it were working at the same bank, and in similar positions, to their German colleagues. The ways in which one describes The City's cultural globalisation is thus influenced by one's origins, experiences and past career.

The City is also defined in terms of what it is not. Behind the descriptions which German interviewees gave of The City, there seemed to be an implicit contrast to Frankfurt; Frankfurt is smaller, newer, less aesthetically pleasing in their eyes, is less multicultural, and contains less in the way of high culture and shopping opportunities. Most were surprised when I said that I enjoyed my visits to Frankfurt, and were dismissive when I explained that I liked visiting its museums and markets. None of my interviewees seemed interested in talking about the Frankfurt Book Fair or other globally-focused cultural activities. As with Beaverstock et al.'s interviewees, most described Frankfurt as focused on 'local business' (2001: 22). People were more ambivalent as to whether or not Frankfurt was 'German' or 'global', however, whilst few described Frankfurt as 'global', all admitted that it had global engagements, and would only go so far as to describe it as 'German-focused' rather than 'German'. Most seemed to associate Frankfurt with the Euro, which was a problematic symbol at the time, as the Euro was replacing the Deutschmark, which was a strong symbol of German identity, particularly for West Germans (Mazzacelli 1995). Frankfurt's embracing of the Euro thus simultaneously encompasses discourses of global, local 
and European identity; with Frankfurt being perceived as global in a more specialised way and centering around the Euro currency market, the Eurozone and 'banking' (as opposed to more general financial services). However, Frankfurt is only 'not global' or 'European' in contrast to London; thus, the two cities are defined with reference to each other, and my interviewees construct them as having quite different forms of globalisation.

The construction of both cities is not developed in a vacuum or without engagement with other groups. Two-thirds of the employees of even the most German-focused bank in The City are English and in particular young and financially-focused English people; whilst few bank employees outside of top management had contact with employees of the Corporation of London or think-tank members. This explains the focus on finance and consumption within The City, and the lack of emphasis on its politics. In addition, London's German transnational business people are influenced by the local culture of Germany, even whilst they are resident elsewhere. The way the Germans underplayed the British class system also suggests influence from Germany; for, whilst there exists some social stratification, Germany lacks England's hereditary class structure (Panayi 1993: 255). Finally, even a relatively homogenous part of London may seem cosmopolitan and multicultural to Germans who, despite initiatives aimed at raising awareness, largely view multiculturalism as something which happens in other countries (Vertovec 1996: 383). Global cities are thus constructed as such with reference to local groups, cultures and events, and construct these in their turn.

\section{Analysis}

Transnational business people thus define and experience global cities, not so much as nodes in a network or as parts of a disconnected global culture, but according to complicated social maps involving reference to both global and local aspects of the same city, differing ways and degrees of 'being global', and to the social maps of other groups. Thus, we need to consider what this situation implies about the culture of the transnational business people and how transnational groups in general relate to the global and the local. The assumption that global cities form nodes in a global network, detached from (albeit existing in) local spaces is one which also assumes that their inhabitants exist in a similarly detached way. However the evidence instead suggests the presence of a complex array of connections to locations of varying degrees of global or local orientation. What is it about the culture of transnational business people which has caused this to be so? and what are the implications for the received theory of the nature of the 'global city'?

Due to their engagement with globalisation, both The City and Frankfurt can be described as 'postmodern', in Harvey's (1989) sense of being comprised of flux, fragmentation and discontinuity, linked to technological change. Transnational business people often voice feelings that they are experiencing ever-more-rapid social changes around them, and tend to emphasise communications technology and travel, both in conversation and in daily activity (Leyshon and Thrift 1997; see also Augar 2000). Global cities are an example of a postmodern culture: globally engaged, in continuous flux, driven by changes in technology and transportation, and inhabiting, in a sense, a discontinuous, Utopian space - a place of people living, as one German auditor put it, 'above the Earth'. The nature of global cities means that they are 
disconnected, fragmented and postmodern, rather than embodying a single form of engagement with other cultures.

The business people whom I interviewed included a diversity of types, persons, professions and life histories. Business people may seem to form an undifferentiated transnational social group when considered as a unit, but, within this, one can see a number of differences with regard to length of (expected or actual) stay in London, reasons for coming to London, areas of origin, professional specialty and so forth; additionally, these identifying factors vary over the course of an individual's career. Like global cities themselves, transnational business people comprise a number of different elements within the global financescape, have different sorts of engagement with outside localities and global entities and construct the cities which they inhabit accordingly. Each person displays varying degrees of engagement with global and local social spaces over the course of their life cycles: a trainee on an international assignment, for instance, has a different relationship with The City to a junior manager who is shortly to go on maternity leave, or to a specialist who travels the globe, visiting all the bank's branches over the course of a year.

The construction of complex social maps, therefore, allows transnational business people to negotiate between global and local social spaces, and different orientations to the global and the local, depending on their age, status, job description and relationship with one or more global cities. The cities themselves can vary in degree and kind of global orientation depending on how individuals and groups position them on their social maps; furthermore, these maps are constructed with reference to those of other actors whom transnational business people encounter, and with reference to the different specialities and orientations of the cities in which they work. It seems, therefore, that 'global' and 'local' are less conditions in and of themselves, as directions, as it were, on a social map, which vary over time and according to the environment. The importance of the practice of social mapping to transnational groups means that the relationship between global cities, and between global cities and local areas, is more complex than stereotypically suggested.

\section{Conclusion}

Among transnational business people we do not see a sharp, definite division between global and local cities, nor between global and local social spaces. Rather, such individuals construct complex social maps which continually change in orientation depending on their needs and strategies for success. In researching transnational groups, therefore, anthropologists need to think less in terms of 'global' versus 'local', and more in terms of complex relationships between groups of varying degrees and kinds of globalisation. Although the works considered at the outset of this paper define global cities as locations which are disconnected from local space and engaged with global space, in fact, the ways in which these cities are constructed by transnational business people suggest that there are different sorts of global cities, incorporating different sorts of engagement with the global and the local. Likewise, they suggest that transnational business people are themselves not a 'global culture' existing with little reference to the local, but people with complex connections to various global and local groups. Future research in this area should, therefore, focus on developing a more complex model of global-local relations among transnational actors. 


\section{References}

Ardener, S. 1993. Ground rules and social maps for women: an introduction. In S. Ardener (Ed.), Women and space, Oxford: Berg.

Augar, P. 2000. The death of gentlemanly capitalism: the rise and fall of London's investment banks. London: Penguin Books.

Beaverstock, J.V. 2002. Transnational elites in global cities: British expatriates in Singapore's financial district. Geoforum 33, 525-538.

--- and Smith, J. 1996. Lending jobs to global cities: skilled international labour migration, investment banking and the City of London. Urban Studies, 33 (8), 13771394.

--- et al. 2001 Comparing London and Frankfurt as world cities: a relational study of contemporary urban change. London: Anglo-German Foundation.

Binney, G. 1993. The British company and the German company compared. In G. Binney (Ed.), Debunking the myths about the German company. London: Chameleon Press.

Courtney, C. and Thompson, P. 1996. City lives: the changing voices of British finance. London: Methuen.

Gall, L. et al. 1995. The Deutsche Bank 1870-1995. London: Weidenfeld and Nicholson.

Gullick, C.J.M.R. 1993. Cultural values and European financial institutions. In T.M. Wilson and M.E. Smith, eds., Culture change and the new Europe, Oxford: Westview Press.

Hannerz, U. 1996. Transnational connections: culture, people, places. London: Routledge.

Harvey, D. 1989. The condition of postmodernity: an enquiry into the origins of cultural change. Oxford: Blackwell.

Jenkins, A. 1988. The City: London's square mile. London: Viking Kestrel.

Jones, A. 2002. The 'global city' misconceived: the myth of 'global management' in transnational service firms. Geoforum 33, 335-350.

Lascelles, D. 1999. Le prix de l'Euro: competition between London, Paris and Frankfurt. CSFI Report No. 37.

Lewis, M. 1989. Liar's poker: two cities, true greed. London: Hodder and Stoughton.

Leyshon, A. and Thrift, N. 1997. Money/Space: geographies of monetary transformation, London: Routledge.

Mazzacelli, C. 1995. Germany at Maastricht: diplomacy and domestic politics. In A.B. Shingleton et al. (Eds.), Dimensions of German unification: economic, social and legal analyses. Oxford: Westview Press.

Millar, J. 1979. British management versus German management: a comparison of organisational effectiveness in West German and UK factories. London: Saxon House. 
Panayi, P. 1993. Germans in London. In N. Merriman (Ed.), The peopling of London: fifteen thousand years of settlement. London: Museum of London.

Rose, H. 1994. London as an international financial centre: a narrative history. London: City Research Project.

Sassen, S. 1991. The global city: New York, London, Tokyo. Princeton: Princeton University Press.

---- 2002. Introduction: locating cities on global circuits. In S. Sassen, ed., Global networks, linked cities. London: Routledge.

Sklair, L. 2001. The transnational capitalist class. Oxford: Blackwell.

Taylor, P.J. et al. 2002. Firms and their global service networks. In S. Sassen, ed., Global networks, linked cities. London: Routledge.

Vertovec, S. 1996. Berlin Multikulti: Germany, 'foreigners' and 'world-openness'. New Community. 22 (3), 381-399.

Watson, A. 1995. The Germans: who are they now? London: Methuen.

\section{About the author}

Dr Fiona Moore is a business anthropologist whose main research interests include symbolism and the construction of identity, the social impact of globalisation, Germany, Europe and economic migration. Following the completion of a doctorate on transnational bankers, she is currently doing research on German automobile manufacturers in the UK. 